\title{
LAND USE AND LAND COVER MAPPING IN DETAILED SCALE: A CASE STUDY IN SANTA ROSA DE LIMA-SC
}

\section{Mapeamento da cobertura e uso da terra em escala detalhada: um estudo de caso em Santa Rosa de Lima-SC}

Rodrigo de Campos Macedo ${ }^{1}$ - ORCID: 0000-0002-5345-7149

Abdon Luiz Schmitt Filho ${ }^{2}$ - ORCID: 0000-0002-3553-7727

Joshua C. Farley ${ }^{3}$ - ORCID: 0000-0002-5793-5240

Alfredo Celso Fantini ${ }^{2}$ - ORCID: 0000-0002-4913-4363

Ademir Antonio Cazella ${ }^{2}$ - ORCID: 0000-0002-4457-4853

Paulo Antonio de Almeida Sinisgalli ${ }^{4}$ - ORCID: 0000-0001-7822-3499

${ }^{1}$ Instituto Brasileiro de Geografia e Estatística - IBGE, Unidade Estadual em Santa Catarina. Rua Tenente Silveira, 94, Andar 12 - CEP 88010-301 - Florianópolis - SC, Brazil rodrigo c macedo@yahoo.com.br

${ }^{2}$ Universidade Federal de Santa Catarina - UFSC, Centro de Ciências Agrárias - CCA, Florianópolis SC, Brazil

${ }^{3}$ University of Vermont - UVM, Gund Institute, Burlington - VT, USA

${ }^{4}$ Universidade de São Paulo - USP, Instituto de Energia e Ambiente - IEA, São Paulo - SP, Brazil

Received in February 14 ${ }^{\text {th }}, 2017$

Accepted in March 29 ${ }^{\text {th }}, 2018$

\section{Abstract:}

It is challenging to reconcile large scale data with the dynamic characteristics present in land use. Such dynamism requires data with a high repetition of sampling. An alternative is the integration of data of high spatial resolution and low temporal resolution, with that of high temporal resolution and low spatial resolution. The aim addressed in this article is related to the integration of aerial photographs and temporal series for land use and land cover mapping in high detail scale. We conducted a case study in Santa Rosa de Lima-SC. The main data used was the aerial survey that overlaid the state of Santa Catarina, executed in 2010/2011. The interpretation key included typical elements of photointerpretation (color, texture, size, shape), aiming to classify the land use and land cover classes. The mapping evaluation resulted in 75.6\% global accuracy, ranging from 54\% (Grassland and Wetlands) to 96\% (Water Bodies and Rocks). Such results are considered satisfactory. The integration of high-resolution images with high temporal resolution data has enabled the discrimination between classes that present great difficulties of separability. Such discrimination is essential in the territorial management processes of Encosta da Serra and the municipality of Santa Rosa de Lima.

Keywords: change detection, image interpretation, temporal series.

How to cite this article: Macedo, R.C., et al. Land use and land cover mapping in detailed scale: a case study in Santa Rosa de Lima-SC, Vol. 24, issue 2, 217-234, Apr-Jun, 2018. 


\section{Resumo:}

É um desafio compatibilizar dados em grandes escalas com as características de dinamismo presentes no uso da terra. Tal dinamismo requer dados com alta repetição de amostragem. Uma alternativa é a integração de dados de alta resolução espacial e baixa resolução temporal, com aqueles de alta resolução temporal e baixa resolução espacial. O objetivo deste artigo consiste em integrar fotografias aéreas com séries temporais de índices de vegetação para o mapeamento de cobertura e uso da terra em escala de grande detalhe. Foi conduzido um estudo de caso em Santa Rosa de Lima-SC. O principal insumo utilizado foi o aerolevantamento que recobriu o Estado de Santa Catarina, realizado em 2010/2011. A chave de interpretação levou em consideração elementos típicos de fotointerpretação (cor, textura, tamanho, forma) e interpretação das séries temporais dos índices de vegetação, visando classificar os tipos de cobertura e uso da terra. A avaliação do mapeamento resultou em 75,6\% de exatidão global, variando de 54\% (Pastagens e Áreas Úmidas) a 96\% (Corpos d’água e Afloramento Rochoso). Tais resultados são considerados satisfatórios. A integração de imagens de alta resolução espacial com dados de alta resolução temporal possibilitou a discriminação entre classes que apresentam grandes dificuldades de separabilidade. Tais discriminações são essenciais nos processos de gestão territorial da Encosta da Serra e do município de Santa Rosa de Lima.

Palavras-chave: detecção de mudanças, interpretação de imagens, séries temporais.

\section{Introduction}

According to FAO (1976), the land cover is the globe's surface segment defined in space and recognized in terms of characteristics and properties comprised by the attributes of the biosphere, which are reasonably stable or cyclically predictable. These attributes include: air, soil, geological substratum, relief, hydrology and the results of human activity. Land cover is related to the biophysical state of the Earth's surface and its immediate subsurface (Turner II et al. 1995). It is composed of natural elements, such as vegetation, water, ice, bare rock, sand and similar surfaces (Anderson 1971; Anderson et al. 1972; Hardy and Anderson 1973; Bie et al. 1996). Moser (1996) points out that the term was expanded to include anthropic structures such as buildings or paved areas.

The term 'land use' may be understood as the way in which space is being occupied by human society - i.e., or human activity directly related to the land. Land use relates to the way that it is used by the local human population (Turner and Meyer 1994; Lambin et al. 2000). It is composed of anthropic activities related to an area of land, with the intention of obtaining products and benefits through the use of resources. In other words, it relates to socio-economic functions e.g, agriculture, housing, environmental protection areas, among others (Heymann et al. 1994). Land use and land cover knowledge is a powerful benefit for various studies and analyses, such as the measurement of physical and environmental accounts, the determination of indices related to welfare, assessment of the anthropism, monitoring of habitats and related ecosystem services, etc. Updated information on land use and its distribution are essential for the efficient management of agricultural and forest resources. Land use and land cover mapping contributes to the link between the physical environment and the socioeconomic one. It is essential in 
environmental studies, decision-making in planning and design of the territory, and the definition of natural resource management policies (Wright 1982).

In land use and land cover surveys, proper registration of the type of cover/use should follow a uniform classification system, aiming to facilitate photointerpretation and comparative analysis. Furthermore, it must adopt the most compatible scale with the level of detail that you want to get to. In the case of detailed surveys, such as maps at the local level, the survey is usually based on aerial photographs, aerophotogrammetric mosaics, satellite images, and mainly on fieldwork (Veldkamp et al. 2001).

At the municipal level, the management of natural resources and emergency operations require thematic data on large scales. A detailed or large scale can be considered as a scale greater than 1: 25,000 (Joly 2004; Duarte 2008). Land use and land cover mapping coupled to a cadastre system reveals the spatial distribution of the types of cover/use. In general, it is the first feature that the user has to locate in the area of interest and identify the uses practiced on it.

It is a challenge to match great detail data with the dynamic characteristics present in land use. To do this requires data with high repeated sampling (Jianya et al. 2008). To overcome this challenge, an alternative is the integration of high spatial resolution data (and low temporal resolution) with high temporal resolution data (and low spatial resolution), such as aerial photographs integrated with satellite data with high sample rates (Inspire 2002), such as MODIS satellite and its vegetation indexes EVI (Enhanced Vegetation Index), and NDVI (Normalized Difference Vegetation Index). Barbosa et al. (2015) integrated high-resolution images with low spatial resolution and high temporal resolution images, aiming to discriminate between different types of pastures, and they found that this integration made it possible to obtain good results.

The use of data from different sensors with spatial resolutions and different ranging time, such as aerial photographs and the time series of vegetation indices, aim towards land cover and land use classes discrimination at the local level, and make up the motivation for this research. The proposed integration can better subsidize public socio-environmental policies.

Time series analysis originated in global ocean and atmospheric studies. However, it was soon applied to sensing the earth's surface, mainly related to issues of land use and cover change (Lambin and Linderman 2006). Several studies have demonstrated the potential application of time series of satellite images for the generation and improvement of land use and land cover maps, and for monitoring agricultural production (Wardlow et al. 2007; Galford et al. 2008; Conrad et al. 2011).

In the last fifteen years, the use of multi-temporal data in remote sensing has become an effective tool, and increasingly necessary for natural resources monitoring (Defries et al. 2004).

The global accuracy was determined by dividing the hits (diagonal in the confusion matrix) by the quantity of observations. Regarding the error matrices, the quantity of hits divided by the number of observations (for each class) is called the 'producer's accuracy'. With it, it is possible to estimate the error of omission. The quantity of hits divided by the number of samples on the thematic map (for each class) is called 'consumer accuracy'. With it, it is possible to estimate the error of commission

The major aim addressed in this article is related to the high spatial resolution data integration procedure (aerial photographs) with high temporal resolution data (time series of vegetation index) for land use and cover mapping in great detail scale, improving the photointerpretation. The specific aims of this article are: to deepen the discussion of the methodological procedure of integration and data mentioned above; present the technical details of the procedures used in the empirical research and the results obtained from land use and land cover mapping by photointerpretation, in Santa Rosa de Lima-SC. 
This article is an integral part of the projects named "Synergies between Ecosystem Services and Agroecology in the Atlantic Forest" and "Analyzing Ecosystem Services from Agroecology in the Atlantic Forest: a Participatory Modeling Approach", in execution at the Federal University of Santa Catarina, with partnerships at the University of Vermont/Gund Institute and University of São Paulo.

\section{Case study description}

\subsection{Study area}

Santa Rosa de Lima is $202 \mathrm{~km}^{2}$ large and has about 2,100 inhabitants (IBGE 2015b). This city, in the state of Santa Catarina, was entitled Santa Catarina's Capital of Agroecology. This title is associated with the pioneering spirit and the significant amount of properties with agroecological production. The study area is contained in the priority area for sustainable use policies of the Ministry of Environment (MMA 2000). Fig. 1 expresses its location in Brazil and Santa Catarina.

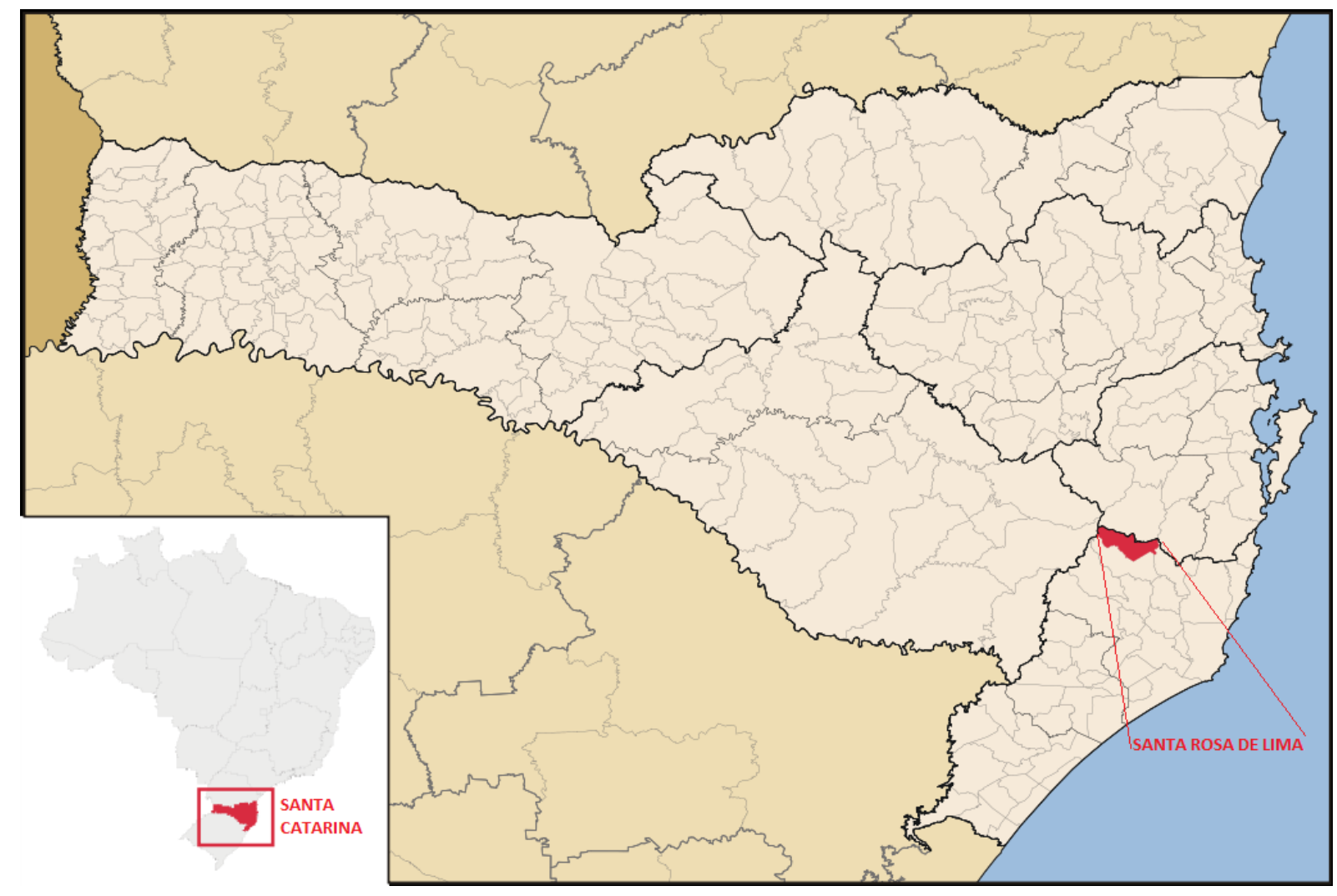

Figure 1: Location of Santa Rosa de Lima in Brazil and Santa Catarina State.

Source: https://pt.wikipedia.org/wiki/Santa Rosa de Lima (Santa Catarina) 


\subsection{Data and software used}

The main data source used was the city's aerophotogrammetric mosaic. This mosaic refers to the aerial survey that overlaid the state of Santa Catarina, held in 2010/2011, using the Airborne Digital Image Acquisition and Post-Processing System, with $C C D^{1}$ sensor. Santa Rosa de Lima was sampled in 2010 in a same airborne survey. It has the following characteristics:

- 0.39 m spatial resolution;

- 12 bits radiometric resolution;

- images available in RGB (Red Green Blue) and CIR (Color InfraRed).

Details about the pre-processing, radiometric adjustment and orthorectification can be obtained in Ruy et al. (2012). In addition to the mosaic, various support inputs were also used. The secondary data was intended to help in the resolution of questions aroused during the interpretation of the main input. These support inputs are used according to demand, and they can be divided into images and temporal series:

- $\quad$ product MOD130 time series (Nasa, 2015);

- Google Earth images, multi-temporal and multi-resolution (to resolve doubts);

- Land cover and land use map in the state of Santa Catarina, in 1:50,000 scale (to resolve doubts) (Geoambiente 2008). This map was made with Spot images of 2005.

Regarding the applications used, the main one was the QGIS Pisa 2.10 - interpretation of images, vectorization screen, rasterization - with the support of the following:

- Virtual Lab time series of remote sensing images (Series View) (Freitas et al. 2011; Sato et al. 2011);

- Vegetation Temporal Analysis System (SatVeg) (Embrapa 2015);

- Google Earth.

\subsection{Procedures}

The mapping parameters adopted were the following:

- scale: 1:10,000;

- datum: SIRGAS 2000;

- minimum mappable area: $40 \mathrm{~m}^{2}$;

- projection: UTM.

In Table 1, it is possible to see land cover classes, land use classes, and a combination of both, with three levels of aggregation. In Table 2, it is possible to verify the concept of each considered class, with representative pictures (IBGE 2015a).

The "Native non-forest vegetation" will be classified as "Grassland vegetation and wetland areas". There is no guarantee it is a land cover class or land use class, that is, there may be

${ }^{1}$ Charge Coupled Device. 
anthropism or not. The "Exotic non-forest vegetation" will be classified as "Pastures" or "Crops" and the "Exotic forest vegetation" will be considered "Silviculture"; with both being considered land use (anthropism).

Table 1: Land cover and land use classes and their respective levels of aggregation.

\begin{tabular}{|c|c|c|}
\hline \multicolumn{3}{|c|}{ Land cover classes } \\
\hline \multicolumn{3}{|c|}{ Levels } \\
\hline $\mathbf{I}$ & II & III \\
\hline \multirow{4}{*}{ Non-vegetated areas } & Water bodies & Water bodies \\
\hline & Urban area & Urban area \\
\hline & Rocky outcrop & Rocky outcrop \\
\hline & Bare land & Bare land \\
\hline \multirow[t]{4}{*}{ Vegetation } & \multirow[t]{2}{*}{ Non-forest vegetation } & Native non-forest vegetation \\
\hline & & Exotic non-forest vegetation \\
\hline & \multirow[t]{2}{*}{ Forest vegetation } & Native forest \\
\hline & & Exotic forest vegetation \\
\hline \multicolumn{3}{|c|}{ Land use classes } \\
\hline \multicolumn{3}{|c|}{ Levels } \\
\hline $\mathbf{I}$ & II & III \\
\hline Water bodies & Water bodies & Water bodies \\
\hline Urban use & Urban use & Urban use \\
\hline \multirow{2}{*}{ Areas without significant anthropism } & Rocky outcrop & Rocky outcrop \\
\hline & Non significantly anthropic vegetation & Non significantly anthropic vegetation \\
\hline Bare land & Bare land & Bare land \\
\hline \multirow{6}{*}{ Anthropic vegetation } & Anthropic grassland & Anthropic grassland \\
\hline & Planted pasture & Planted pasture \\
\hline & Silviculture & Silviculture \\
\hline & \multirow{3}{*}{ Crops } & Seasonal crops \\
\hline & & Permanent crops \\
\hline & & Agroecological mosaics \\
\hline \multicolumn{3}{|c|}{ Land use and cover classes (combined subtitles) } \\
\hline \multirow{11}{*}{ Not applicable } & \multirow{11}{*}{ Not applicable } & Water bodies \\
\hline & & Urban area \\
\hline & & Rocky outcrop \\
\hline & & Bare land \\
\hline & & Native forest \\
\hline & & Silviculture \\
\hline & & Grassland vegetation and wetland areas \\
\hline & & Pastures \\
\hline & & Seasonal crops \\
\hline & & Permanent crops \\
\hline & & Agroecological mosaics \\
\hline
\end{tabular}


In the next paragraphs there will be presented the conceptualization of adopted land use and land cover classes and the illustrations is presented on the Figure 2.

Water bodies Includes all inland waters, such as waterways and canals (rivers, streams and other linear water bodies), naturally closed water bodies without movement (regulated natural lakes) and artificial reservoirs (artificial dams built for irrigation, flood control, water supply and power generation).

Urban areas are the urban use structured by buildings and road systems, dominated by nonagricultural artificial surfaces. Included in this category are the city, road areas, services and transport, power lines, communication and associated land, occupied areas by agribusinesses and buildings that can, in some cases, be located in the urban perimeter. Urban landscaping, parks, vacant lots, or any urban green area is also contained in this class.

Rocky outcrop is the surface areas predominantly covered by rocks, blocks and debris. They are rocky outcroppings, cliffs and quarries, including abandoned extraction sites and areas without vegetation. Bare lands are areas with active erosion processes, also including areas of gravel accumulation along the rivers and freshwater beaches.

Native forests are areas considered as forest, with tree formations, including areas of dense forest (forest structure with continuous top cover), open forest (forest structure with varying degrees of discontinuity of the top cover, as is typical with lianas, bamboo, palm or sororoca), seasonal forest (forest structure with loss of upper strata leaves during unfavorable seasons - dry and cold); and Araucaria forest (forest structure comprises the natural range of Araucaria, a striking element in the upper strata, which generally forms continuous coverage).

Silviculture is a forest area with farming activity, planted with exotic species, especially eucalyptus and pine trees.

Grassland vegetation and wetland are areas with non-arboreal formation predominance. It is understood as grassland, with different categories that are physiognomically different from forests, in other words, those that are characterized by a predominant layer of shrubs, sparsely distributed over a woody grassy carpet. Included in this category are: native grasslands, savannas, steppes, steppe-like savannas, pioneer formations and ecological refuges. Also included are areas permanently or periodically flooded with fresh water (swamps, bogs, fens, marshes etc). These areas can have shrub and woody vegetation, provided that they occupy an area of less than $10 \%$ of the total.

Pastures are areas predominantly occupied by cultivated herbaceous vegetation. These are places for cattle grazing and other animals, formed by planting perennial forage, subject to highintensity anthropogenic interference, such as land cleaning (stumps and rocks). This also includes areas occupied by grassland subject to grazing and other low-intensity anthropogenic interference.

Seasonal crops are predominantly irrigated and non-irrigated annual crops, defined as land used for food, fiber and agribusiness commodities. This includes all cultivated land, characterized by the design of cultivated or fallow areas and can also comprise cultivated wetland areas.

Permanent crops are predominantly perennial crops; may constitute heterogeneous agricultural areas. Agroecological mosaics are places where it is not possible to separate classes, with respect to the smallest mappable area. In these places, there may be mixtures of heterogeneous agricultural areas, remnants of native vegetation, forest regeneration, grazing, silviculture, regardless of its proportions. This class expresses the complexity present in small family farming 
holdings, displaying heterogeneous, complex and small patterns, subject to discrimination on scales larger than 1:10,000 (e.g., property mapping).

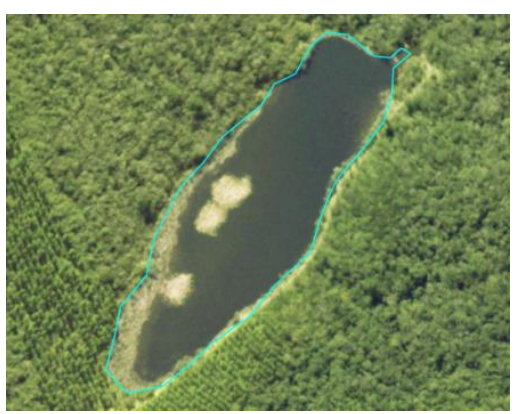

Water bodies

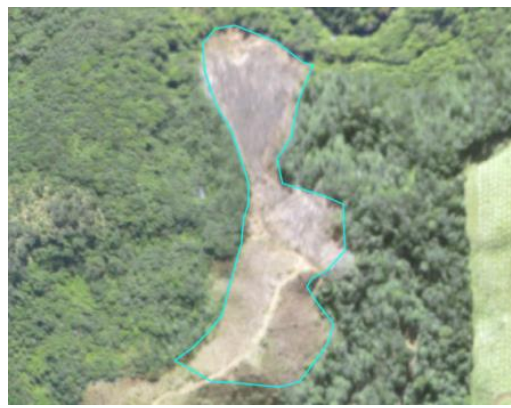

Bare land

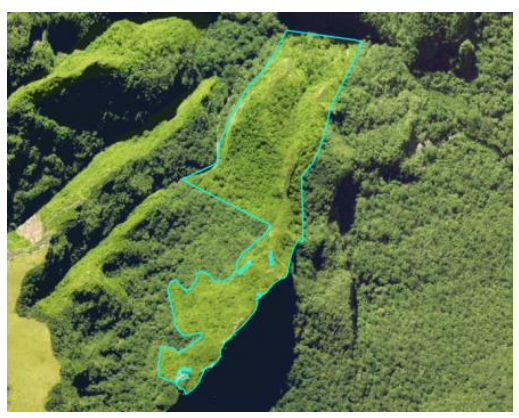

Grassland vegetation and wetland areas

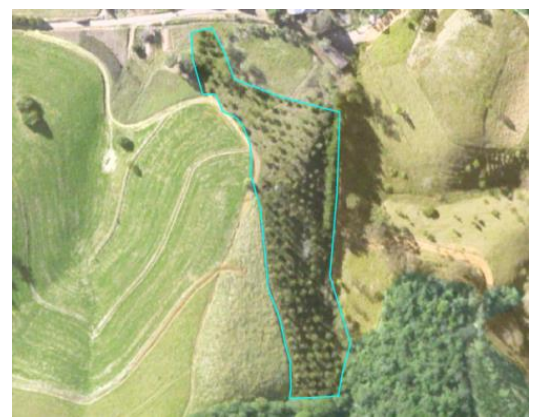

Permanent crops

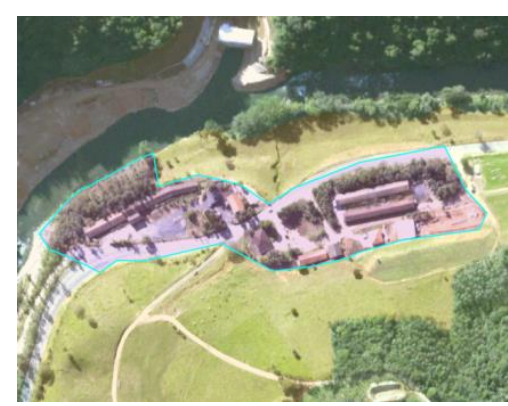

Urban area

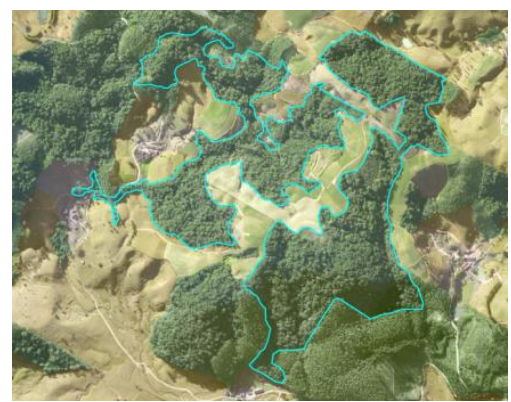

Native forest

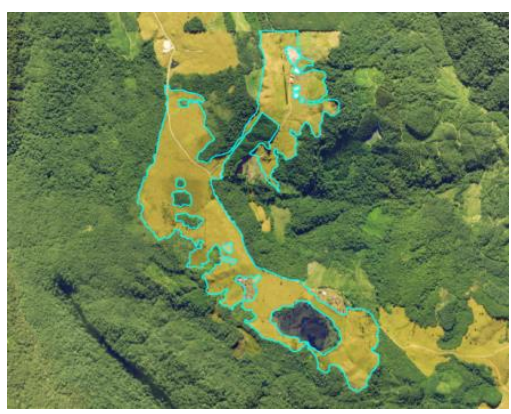

Pastures

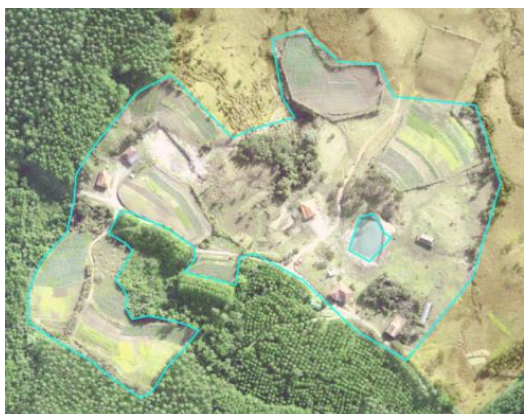

Agroecological mosaics

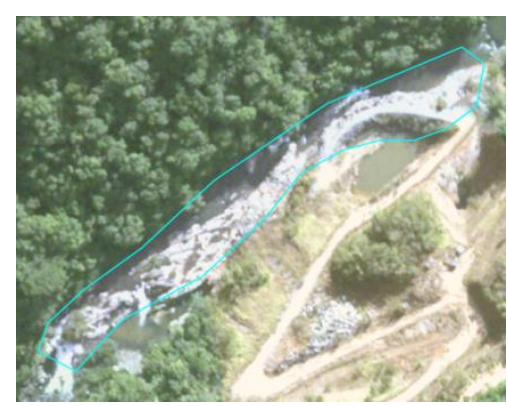

Rocky outcrop

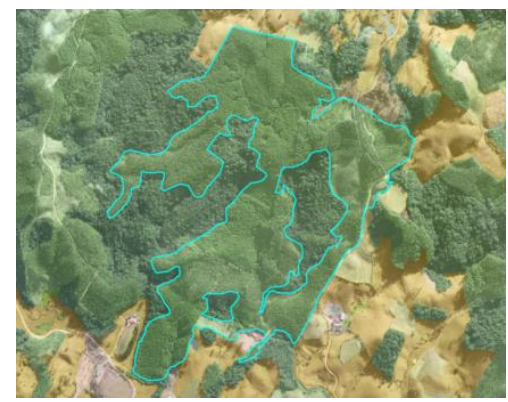

Silviculture

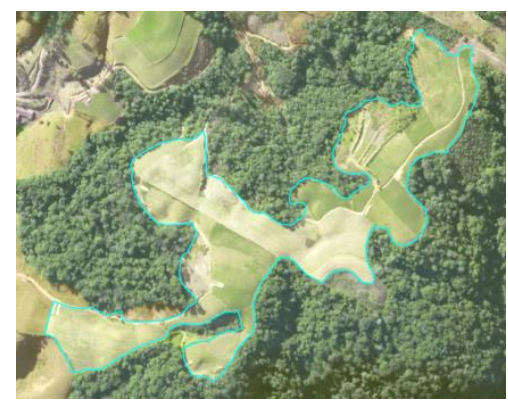

Seasonal crops

Figure 2: Illustration of adopted land use and land cover classes. 
Fig. 3 expresses the methodological scheme adopted.

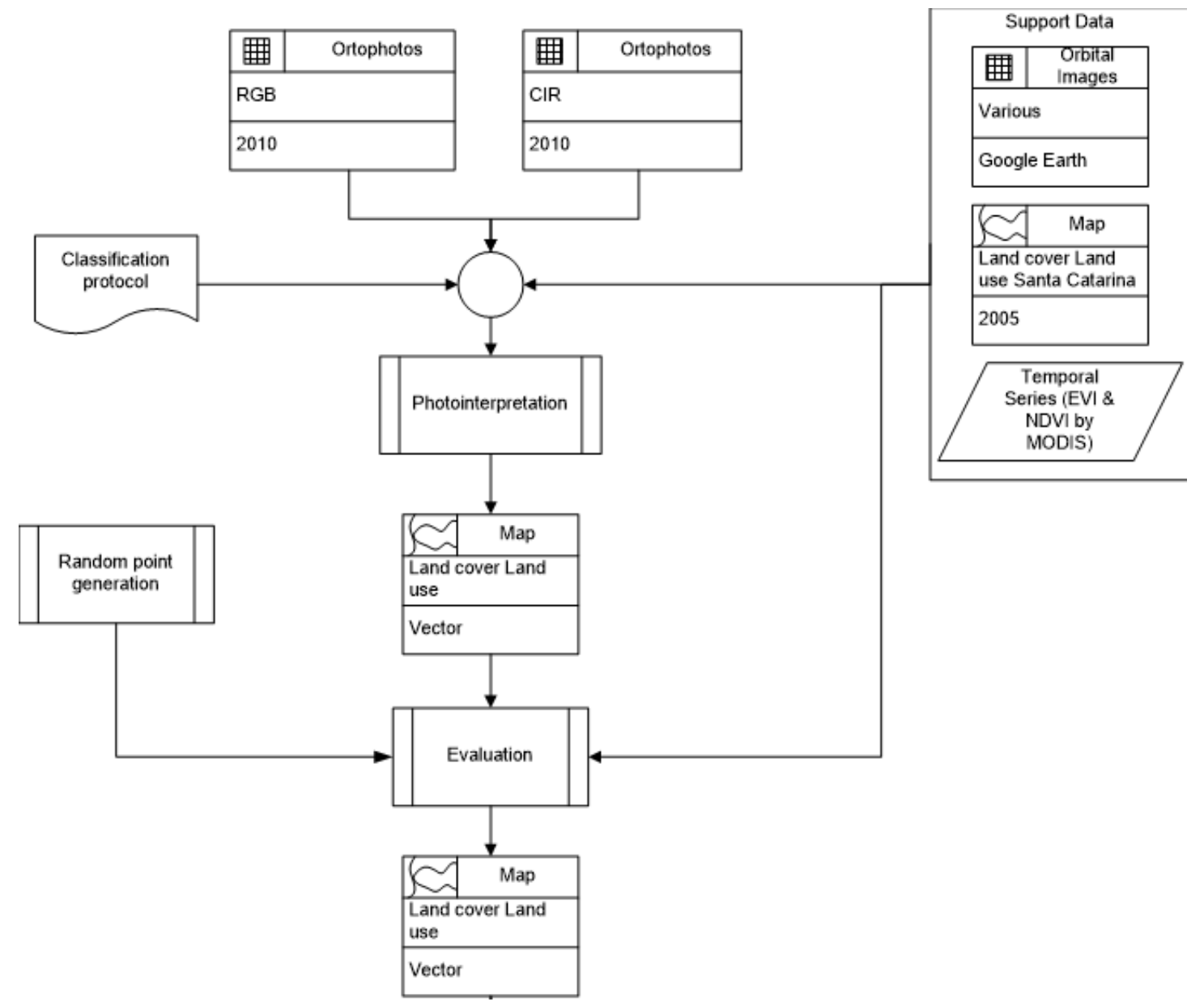

Figure 3: Methodological scheme.

Using the classification protocol (Table 2), the photointerpretation is performed from orthophotos. The data used are photogrammetric mosaics in RGB (Red Green Blue, true color composite) and in CiR (Color InfraRed, composition with infrared close to reddish tones), obtained by Department of Sustainable Development (SDS).

The most important features in photointerpretation of land use and land cover classes are the following: tone/color, texture, pattern, shape, size, shadow, and contextual information. The display scale on the computer screen was approximately 1:500. A sorting key is designed to guide the photointerpretation. The key includes tonal, textural and geometric features of land use and land cover classes. In Table 2, it is possible to relate these classes with the elements of interpretation. 
Table 2: Sorting key to subsidize photointerpretation. Only the RGB Ortophoto was presented.

\begin{tabular}{|c|c|c|c|c|c|c|c|}
\hline Class & $\begin{array}{l}\text { Color/Hue } \\
\text { (RGB/CIR) }\end{array}$ & Texture & Dimension & Shape & Brightness & Seasonality & $\begin{array}{c}\text { Variation } \\
\text { related to } \\
\text { management }\end{array}$ \\
\hline Rocky outcrop & Grayish/Greenish & - & $\begin{array}{l}\text { It tends to be } \\
\text { small }\end{array}$ & $\begin{array}{l}\text { It tends to be } \\
\text { irregular }\end{array}$ & - & No & No \\
\hline Water bodies & Black / Dark & $\begin{array}{l}\text { It tends to be } \\
\text { flat }\end{array}$ & $\begin{array}{l}\text { It tends to be } \\
\text { small }\end{array}$ & $\begin{array}{l}\text { It tends to be } \\
\text { irregular }\end{array}$ & $\begin{array}{l}\text { It tends to be } \\
\text { dark }\end{array}$ & No & No \\
\hline Grassland & $\begin{array}{l}\text { Light green / } \\
\text { Light red }\end{array}$ & $\begin{array}{l}\text { It tends to be } \\
\text { slightly rough }\end{array}$ & - & Irregular & $\begin{array}{l}\text { It tends to be } \\
\text { light }\end{array}$ & Yes & No \\
\hline Urban area & Magenta / Cyano & Rough & $\begin{array}{l}\text { It tends to be } \\
\text { small }\end{array}$ & - & $\begin{array}{l}\text { It tends to be } \\
\text { light }\end{array}$ & No & No \\
\hline Forest & $\begin{array}{l}\text { Dark green / } \\
\text { Dark red }\end{array}$ & Rough & - & Irregular & $\begin{array}{l}\text { It tends to be } \\
\text { dark }\end{array}$ & No & No \\
\hline Seasonal crop & $\begin{array}{l}\text { Light green or } \\
\text { orange / Light } \\
\text { red or orange }\end{array}$ & $\begin{array}{l}\text { It tends to be } \\
\text { flat }\end{array}$ & - & $\begin{array}{l}\text { It tends to be } \\
\text { regular }\end{array}$ & $\begin{array}{l}\text { It tends to be } \\
\text { light }\end{array}$ & Yes & Yes \\
\hline $\begin{array}{l}\text { Agroecological } \\
\text { mosaic }\end{array}$ & - & - & $\begin{array}{l}\text { It tends to be } \\
\text { small }\end{array}$ & - & - & - & - \\
\hline Pastures & $\begin{array}{l}\text { Light green or } \\
\text { orange / Light } \\
\text { red or orange }\end{array}$ & $\begin{array}{l}\text { It tends to be } \\
\text { flat }\end{array}$ & - & $\begin{array}{l}\text { It tends to be } \\
\text { irregular }\end{array}$ & $\begin{array}{l}\text { It tends to be } \\
\text { light }\end{array}$ & A little & A little \\
\hline Permanent crop & $\begin{array}{c}\text { It tends to be } \\
\text { dark green / dark } \\
\text { red }\end{array}$ & Rough & $\begin{array}{l}\text { It tends to be } \\
\text { small }\end{array}$ & $\begin{array}{l}\text { It tends to be } \\
\text { regular }\end{array}$ & $\begin{array}{l}\text { It tends to be } \\
\text { dark }\end{array}$ & A little & A little \\
\hline Silviculture & Green / Red & Intermediate ${ }^{3}$ & - & - & $\begin{array}{l}\text { It tends to be } \\
\text { light }\end{array}$ & No & No \\
\hline $\begin{array}{l}\text { Exposed soil } \\
\text { (bare land) }\end{array}$ & $\begin{array}{c}\text { Orange or } \\
\text { brownish / } \\
\text { Orange or purple }\end{array}$ & Flat & $\begin{array}{l}\text { It tends to be } \\
\text { small }\end{array}$ & $\begin{array}{l}\text { If erosion } \\
\text { (irregular) / if } \\
\text { soil prepare } \\
\text { (regular) }\end{array}$ & $\begin{array}{l}\text { It tends to be } \\
\text { light }\end{array}$ & No & No \\
\hline
\end{tabular}

2 Crop, soil preparation, planting.

3 Rougher than temporary crops and pasture, flatter than native vegetation.

The elements cited in Table 2 help the interpreter to classify the orthophotos and can be better detailed by associating the high resolution image with the temporal data of multispectral images.

Some classes are too complex to be discriminated by photointerpretation from a single scene, on a single date. Typical examples are related to distinctions between grasslands and pastures, and seasonal crops and pastures. Time issue is extremely important, as it allows distinction between seasonal crops (crops and soil preparation) and pastures (few reforms in a long period of time) (Ferreira and Arantes 2014). In these cases, other images, and especially time series of vegetation indexes, were used.

The interpretation of time series consists in verifying the changes in the vegetation index over time (years, months and days, depending on the case). A typical situation is the discrimination between temporary agriculture and pasture. The variation that exists between harvest/soil preparation and the crop ripening period shows a significant difference in the vegetation index 
levels. Instead, pastures do not show significant difference in one year. Even considering seasonality issues, the differences found in the pastures are smaller than in the areas of seasonal crops. The only exception would be due to pasture reform, but such agricultural practice is not common in the region.

Fig. 4 illustrates, through teaching examples, differentiation between some land use and land cover classes, using time series.

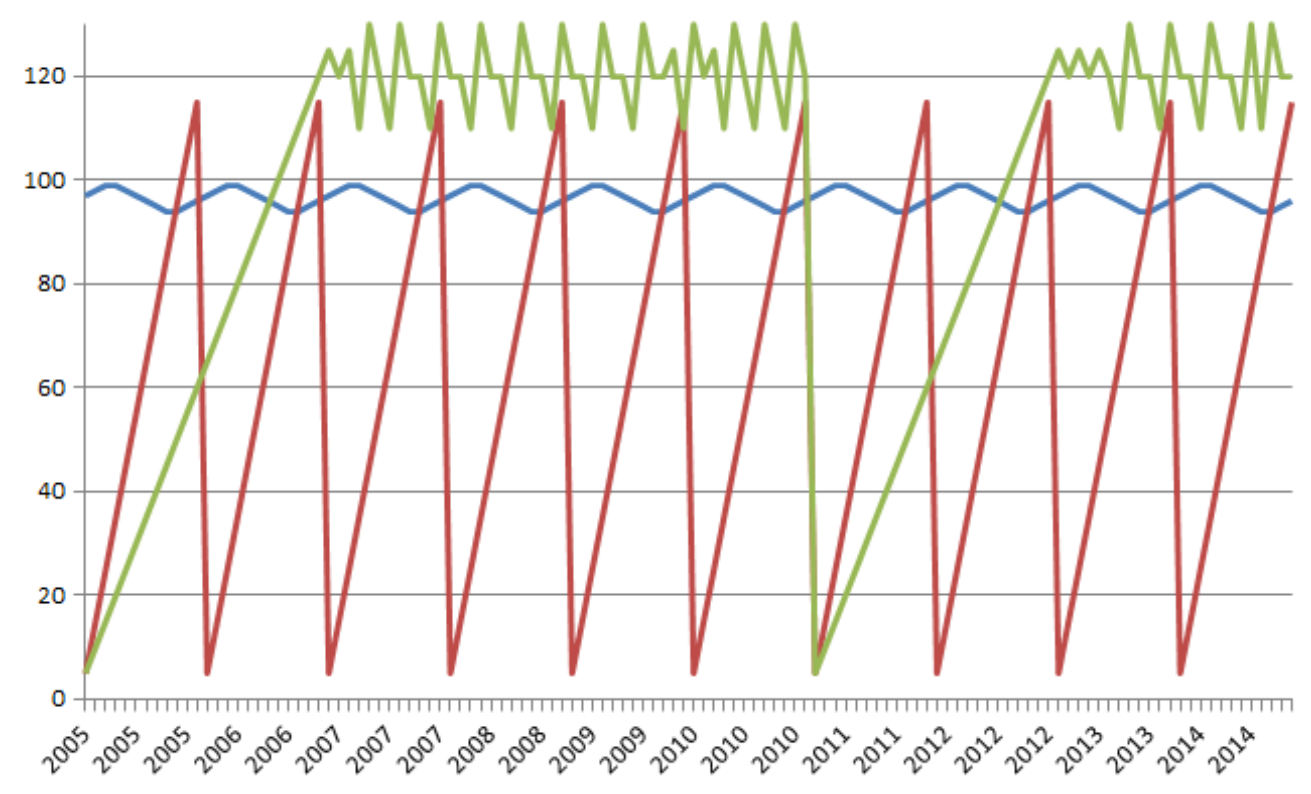

Figure 4: Schematic illustration of the distinction between some land use and cover classes through time series. Classes without seasonal or management practices, such as dense forest (in blue); classes with annual management practices, such as seasonal crops (in red) and management practices classes in long cycle, such as Silviculture (in green).

During the photointerpretation, in order to solve any doubts, several supporting data are used, such as Google Earth images, land use and land cover of Santa Catarina and, mainly, the time series of vegetation indexes of MODIS. These data supports are also used to evaluate the map obtained.

The result of this photointerpretation is the generation of a land use and land cover map in vector format (polygons). This map is evaluated through the random generation of sampling points. At each assessment point, various supporting inputs were verified, such as the land cover map and SC land use, Google Earth scenes), and the time series of MODIS vegetation indexes.

After the verification, a confusion matrix (or error matrix) was calculated, expressing the amount of errors and hits. The global accuracy was determined by dividing the hits (diagonal in the confusion matrix) by the total number of observations. Besides the global accuracy, the kappa index was calculated, an in Equation 1 (Jensen 2005; Mather 2004).

In the end, the vector map is potentially useful for obtaining analyses of tables, graphs, statistics, etc. This map can be converted into a raster format to proceed with modeling routines. 


$$
\hat{\mathrm{K}}=\frac{N \sum_{i=1}^{\kappa} \chi_{i i}-\sum_{i=1}^{\kappa}\left(\chi_{i+} \cdot \chi_{+i}\right)}{N^{2}-\sum_{i=1}^{K}\left(\chi_{i+} \cdot \chi_{+i}\right)}
$$

On what:

$K=$ Number of lines in the matrix of confusion;

$N=$ Total number of observations;

$x i i=$ Number of observations in row $i$ column $i$ (diagonal);

$x i+=$ Number of observations on line $i$;

$x+i=$ Number of observations in column $i$.

In the end, the vector map is potentially useful for obtaining analyses of tables, graphs, statistics, etc. This map can be converted into a raster format to proceed with modeling routines.

\section{Results and Discussion}

It is possible to view the result of the photo-interpretation in Figure 5. From the vector data, the areas of each class were calculated, as it can be seen in Fig. 6.

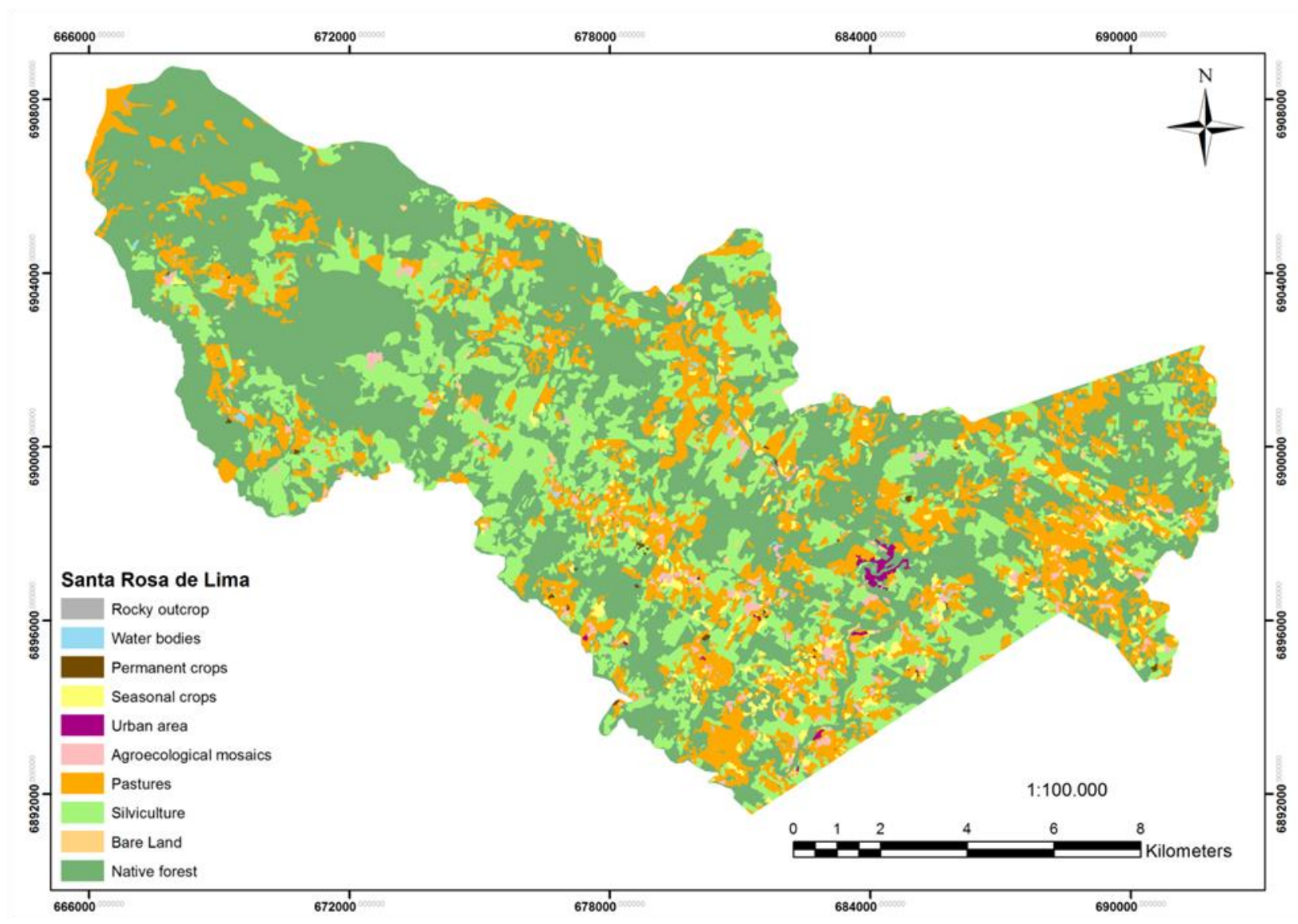

Figure 5: Santa Rosa de Lima's land use and land cover map. The 1:100,000 scale is for display only. 


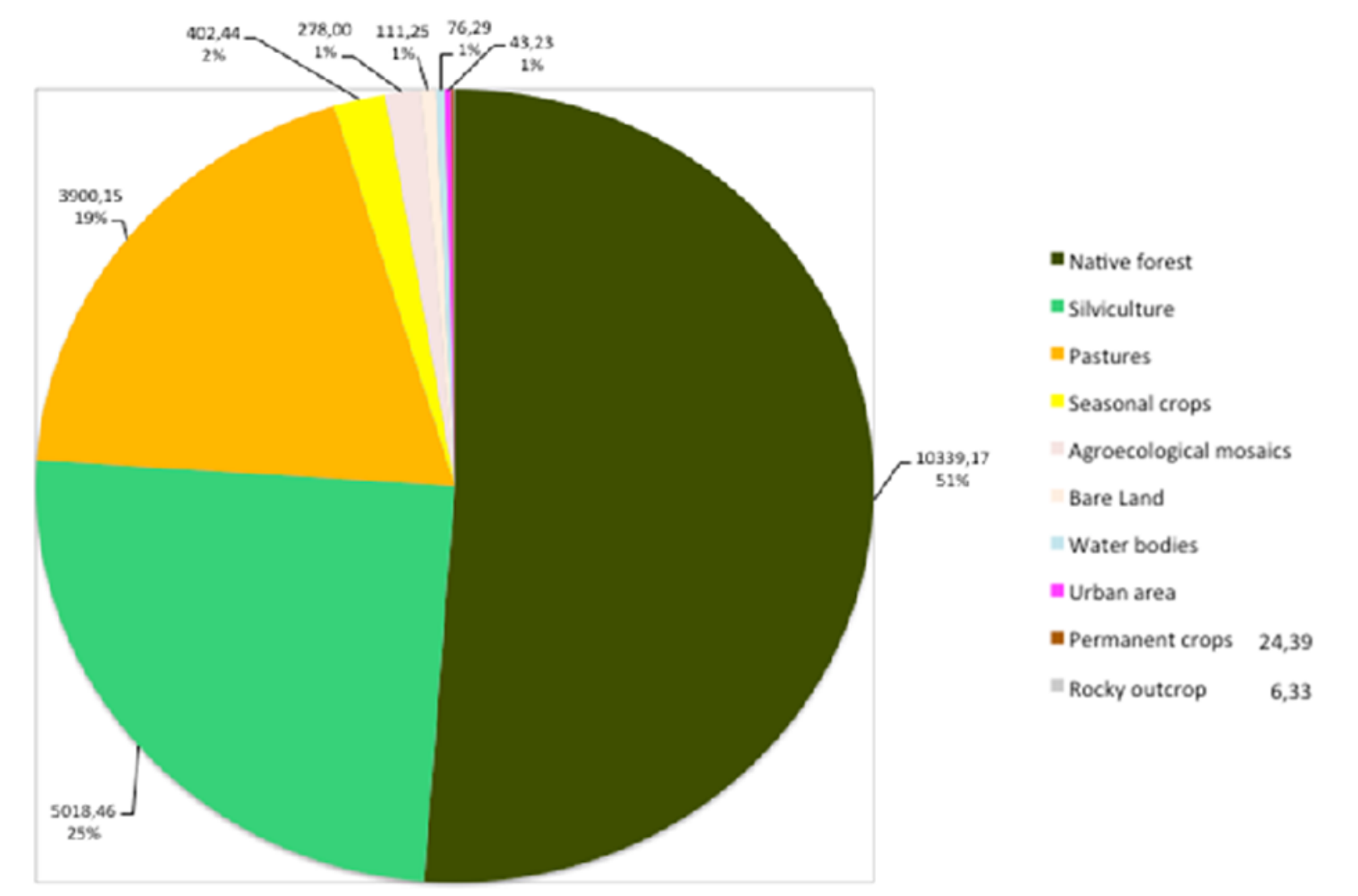

Figure 6: Distribution of Santa Rosa de Lima's land use and land cover. The labels contain the area (ha) and the percentages (1\% were not labeled).The total area is 20,199.70 ha.

The total area occupied by native phytophysiognomies (Native forest and Grassland and Wetlands) is about 10,500ha. The anthropic area is about 9,500ha, expressing a good ratio between low and high anthropism.

There were mixtures and mixed areas in almost all classes, mainly "agroecological mosaics" and "urban area". Even the urban arborization and green areas were contained in the "urban area". The "agroecological mosaic" is highly correlated with farms and their small agriculture. These results are consistent with the results obtained by Noma et al 2013 e Costa et al 2015.

With such information, the confusion matrix was generated and the Kappa index was calculated, as can be seen in the Tables 3 and 4. The mapping evaluation resulted in 75.6\% global accuracy, and the Kappa index by 0.732, ranging from 54\% (Grassland and Wetlands) to 96\% (Water Bodies and Rocks). Such results are considered satisfactory (Stehman 2001; Sano et al. 2008; Pontius and Li 2010). 
Table 3: Confusion matrix (or error matrix).

\begin{tabular}{c|c|c|c|c|c|c|c|c|c|c|c|c}
\hline & $\mathrm{W}^{1}$ & $\mathrm{U}^{2}$ & $\mathrm{R}^{3}$ & $\mathrm{~B}^{4}$ & $\mathrm{~N}^{5}$ & $\mathrm{~S}^{6}$ & $\mathrm{G}^{7}$ & $\mathrm{P}^{8}$ & $\mathrm{CS}^{9}$ & $\mathrm{CP}^{10}$ & $\mathrm{M}^{11}$ & Total \\
\hline $\mathrm{W}$ & 48 & 0 & 1 & 0 & 1 & 0 & 0 & 0 & 0 & 0 & 0 & 50 \\
\hline $\mathrm{U}$ & 0 & 47 & 1 & 2 & 0 & 0 & 0 & 0 & 0 & 0 & 0 & 50 \\
\hline $\mathrm{R}$ & 0 & 0 & 48 & 0 & 0 & 0 & 0 & 0 & 0 & 0 & 2 & 50 \\
\hline $\mathrm{B}$ & 0 & 3 & 0 & 46 & 0 & 0 & 0 & 0 & 0 & 0 & 1 & 50 \\
\hline $\mathrm{N}$ & 1 & 0 & 0 & 0 & 38 & 11 & 0 & 0 & 0 & 0 & 0 & 50 \\
\hline $\mathrm{S}$ & 0 & 0 & 0 & 0 & 10 & 39 & 0 & 1 & 0 & 0 & 0 & 50 \\
\hline $\mathrm{G}$ & 0 & 1 & 0 & 0 & 0 & 0 & 27 & 7 & 6 & 0 & 9 & 50 \\
\hline $\mathrm{P}$ & 0 & 0 & 0 & 0 & 0 & 0 & 11 & 29 & 7 & 0 & 3 & 50 \\
\hline $\mathrm{CS}$ & 0 & 0 & 0 & 5 & 0 & 0 & 8 & 3 & 28 & 0 & 6 & 50 \\
\hline $\mathrm{CP}$ & 0 & 0 & 0 & 0 & 0 & 9 & 0 & 0 & 0 & 36 & 5 & 50 \\
\hline $\mathrm{M}$ & 0 & 0 & 0 & 0 & 0 & 0 & 5 & 9 & 4 & 2 & 30 & 50 \\
\hline Total & 49 & 51 & 50 & 53 & 49 & 59 & 51 & 49 & 45 & 38 & 56 & \\
\hline Source & & & & & & & & & & & & \\
\hline
\end{tabular}

Source: Based on Level III of Table 1.

${ }^{1}$ Water bodies; ${ }^{2}$ Urban area; ${ }^{3}$ Rocky outcrop; ${ }^{4}$ Bare land; ${ }^{5}$ Native forest; ${ }^{6}$ Silviculture; ${ }^{7}$ Grassland vegetation and wetland areas; ${ }^{8}$ Pastures; ${ }^{9}$ Seasonal crops; ${ }^{10}$ Permanent crops; ${ }^{11}$ Agroecological mosaics.

Table 4 Evaluation metrics.

\begin{tabular}{c|c|c|c|c}
\hline & Producer Accuracy & Errors of omission & Consumer Accuracy & Commission Errors \\
\hline W & 0.96 & 0.04 & 0.98 & 0.02 \\
\hline U & 0.94 & 0.06 & 0.92 & 0.08 \\
\hline R & 0.96 & 0.04 & 0.96 & 0.04 \\
\hline B & 0.92 & 0.08 & 0.88 & 0.13 \\
\hline N & 0.76 & 0.24 & 0.78 & 0.22 \\
\hline S & 0.78 & 0.22 & 0.66 & 0.34 \\
\hline G & 0.54 & 0.46 & 0.53 & 0.47 \\
\hline P & 0.58 & 0.42 & 0.59 & 0.41 \\
\hline CS & 0.56 & 0.44 & 0.62 & 0.38 \\
\hline CP & 0.72 & 0.28 & 0.95 & 0.05 \\
\hline M & 0.60 & 0.40 & 0.54 & 0.46 \\
\hline Gobal Accuracy & 0.756 & & & \\
\hline Kappa Index & 0.732 & \multicolumn{5}{|l}{} \\
\hline
\end{tabular}

Congalton and Green (2009) recommend a minimum of 50 samples per class for maps with up to 12 classes and an area of less than 1 million acres. The evaluation was performed using random 
sampling in each class, with a sampling rate of 50 points per class, totaling 550 evaluation points. All supporting data was used to evaluate the mapped class.

It is important to emphasize that different people carried out the photointerpretation and the evaluation. The inputs used were the same, but there was no similarity between the two steps. The photointerpreter consulted the inputs only when doubts arose. The evaluator did not know where the doubts were located. Also, the samples were randomly generated. In this way, the validation has more reliability than the classification.

\section{Conclusion}

Although the photointerpretation does not eliminate subjectivity and, apparently, it is more time consuming than an automated or semi-automated classification procedure, the technique adopted in this work provided high productivity, significant resolution of doubts, and considerable accuracy. A less subjective photointerpretation, helps the decision-making of the photointerpreter. In addition, the photointerpretation elements used in the classification protocol (Table 2) can help start an effort to automate the classification process. For example, through object-based classification.

It is important to emphasize that automatic or semi-automatic classification reduces subjectivity and tends to be more productive, however, the elaboration of the classification rules is complex and relatively time-consuming, especially when involving agriculture, pasture and native vegetation.

The integration of high-resolution images (airborne photographs) with high temporal resolution data (time series vegetation indices) allowed discrimination between classes that presented great difficulties of separability, such as grassland and pastures; pastures and crops; native forest and silviculture. Such discriminations potentiate territorial management capacity at the municipal level, because they allow the proper assessment in terms of economic ecological zoning, for example. This work was important to demonstrate that the integration of data with high temporal resolution and high spatial resolution make it possible to generate maps of land cover and land use in large scales. Besides that, the resulting map is potentially applicable in analysis and modeling, in which land cover and occupation are relevant.

This kind of research is relevant and contains new and significant information, because the use of time series to support photointerpretation is not a routine activity and this integration must be increasingly incremented.

\section{ACKNOWLEDGEMENT}

The authors would like to thank Eloiza Lalane, Caçula, Tilico, Lucio (Epagri), André, Álvaro (UFSC) and the Brazilian Institute of Geography and Statistics -IBGE for providing the realization of this survey. 


\section{REFERENCES}

Anderson, J. R. 1971. Land use classification schemes used in selected recent geographic applications of remote sensing. Photogramm. Eng., v. 37, no. 4, p. 379-387.

Anderson, J. R.; Hardy, E. E.; Roach, J. T. 1972.A land-use classification system for use with remote-sensor data. U.S. Geol. Survey Circ., 671, 16p.

Barbosa, D. P.; Noma, A.; Korting, T. S.; Fonseca, L. M. G. 2015. Um Estudo Experimental com Classificadores baseados em Regiões e Perfis EVI. Annals... XVII Simpósio Brasileiro de Sensoriamento Remoto - SBSR, João Pessoa-PB, Brasil, 25 a 29 de abril de 2015, INPE p. 880-887.

Bie, C. A. J. M.; Leeuwen, J. A. van; Zuidema, P. A. 1996. The land use database: a knowledgebased software program for structured storage and retrieval of user defined land use data sets: user's reference manual. Version 1.04 for MS-DOS. [S.I.]: ITC: FAO: UNEP: WAU. Available in: <http://ces.iisc.ernet.in/energy/HC270799/LM/SUSLUP/Luse/Manual/chap2.pdf>. Access in: 2016.

Congalton, R. G.; Green, K. 2009. Assessing the accuracy of remotely sensed data: Principles and practices. Second edition. Boca Raton: Lewis Publishers.

Conrad, C.; Colditz, R. R.; Dech, S.; Klein, D.; Vlek, P. L. G. 2011. Temporal segmentation of MODIS time series for improving crop classification in Central Asian irrigation systems. International Journal of Remote Sensing, v. 32, n. 23, p. 8763-8778.

Costa, W. S.; Fonseca, L. M. G.; Korting, T. S. Classificação de pastagens cultivadas e formações campestres nativas no Cerrado brasileiro a partir da análise de séries temporais extraídas de índices EVI do sensor MODIS. Annals... XVII Simpósio Brasileiro de Sensoriamento Remoto - SBSR. João Pessoa-PB, Brasil, INPE, p. 1516-1523. 2015.

Defries, R. S.; Asner, G. P.; Houghton, R. A. 2004. Ecosystems and Land Use Change. American Geophysical Union, Washington, DC.

Duarte, P. A. Fundamentos de Cartografia. 3a. ed. Editora da UFSC. Florianópolis. 2008.

Embrapa (Empresa Brasileira de Pesquisa Agropecuária). Sistema de Análise Multitemporal da Vegetação - SATVEG. 2015. Disponível em: <https://www.satveg.cnptia.embrapa.br/>.

FAO (Food and Agriculture Organization). 1976. A framework for land evaluation. Natural Resources. Management and Environment Department. FAO Corporate Document Repository. Rome: FAO; Wagering en: ILRL, (Soil Bulletin, no 29).

Ferreira, L. G.; Arantes, A. E. 2014. Radiografia das pastagens do Brasil. Relatório Parcial Filtragem de Séries-Temporais de Índices de Vegetação - Análise Preliminar. Goiânia, Brazil.

Freitas, R. M.; Arai, E.; Adami, M.; Souza, A. F.; Shimabukuro, Y. E.; Rudorff, B. F. T.; Yuzo, F.; Rosa, R. R. 2011. Visualização Instantânea de Séries Temporais EVI2-MODIS na América do Sul. In: Annals... Simpósio Brasileiro de Sensoriamento Remoto (SBSR), 15, 2011, Curitiba. São José dos Campos: INPE, 2011. p. 6866-6873. 1 DVD. ISBN: 978-85-17-00057-7.

Galford, G. L.; Mustard, J. F.; Melillo, J.; Gendrin, A.; Cerri, C. C.; Cerri, C. E. P. 2008. Wavelet analysis of MODIS time series to detect expansion and intensification of row-crop agriculture in Brazil. Remote Sensing of Environment, v. 112, n. 2, p. 576 - 587.

Geoambiente Sensoriamento Remoto Ltda.; Secretaria de Agricultura e Abastecimento do Estado de Santa Catarina. Projeto de Proteção da Mata Atlântica em Santa Catarina (PPMA/SC). 
Relatório Técnico do Mapeamento Temático Geral do Estado de Santa Catarina. São José dos Campos - SP. 90p. 2008

Hardy, E. E.; Anderson, J. R. 1973. A land use classification system for use with remote sensor data. In: Conference on Machine Processing of Remotely Sensed Data. West Lafayette, IN, 1973. Proceedings. New York, IEEE, p. 2A-1 - 2A-6.

Heymann, Y.; Steenmans, C.; Croisille, G.; and Bossard, M. 1994. Corine land cover technical guide. Luxembourg: European Commission.

IBGE (Instituto Brasileiro de Geografia e Estatística). 2015a. Mudanças na Cobertura e Uso da Terra 2000 - 2010 - 2012. Rio de Janeiro. 48p.

IBGE (Instituto Brasileiro de Geografia e Estatística). 2015b. Portal das Cidades. Available in: <http://www.cidades.ibge.gov.br/> or <http://cod.ibge.gov.br/3SS>. Access in 2015.

INSPIRE (Infrastructure for Spatial Information in the European Community). 2002. Environmental thematic Coordination Group. Environmental thematic user needs - Position Paper, Version 2.

Jensen, J. R. 2005. Introductory digital image processing: a remote sensing perspective. 3. ed. New Jersey: Pearson Prentice Hall, 528 p.

Jianya, G.; Haigang, S.; Guorui, M.; Qiming, Z. 2008. A review of multitemporal remote sensing data change detection algorithms. The International Archives of the Photogrammetry, Remote Sensing and Spatial Information Sciences, v. 37, part B7, Pequim, p. 757-762.

Joly, F. A Cartografia. 6a. ed. Papirus Editora. Campinas. 2004.

Lambin, E. F.; Rounsevell, M. D. A.; Geist, H. J. 2000. Are agricultural land-use models able to predict changes in land-use intensity? Agriculture, Ecosystems and Environment, v. 82, p. 321331.

Lambin, E. F.; Linderman, M. 2006. Time series of remote sensing data for land change science. Geoscience and Remote Sensing. IEEE Transactions, v. 44, n. 7, p. 1926-1928.

Mather, P. M. 2004. Computer processing of remotely-sensed images: an introduction. 3. ed. England: John Wiley \& Sons, 326 p.

MMA (Ministério do Meio Ambiente). 2000. Avaliação e ações prioritárias para a conservação da biodiversidade da Mata Atlântica e Campos Sulinos: Conservation International do Brasil, Fundação SOS Mata Atlântica, Fundação Biodiversitas, Instituto de Pesquisas Ecológicas, Secretaria do Meio Ambiente do Estado de São Paulo, SEMAD/Instituto Estadual de FlorestasMG. Brasília: MMA/SBF, 40p. ISBN: 85-87166-09-3.

Moser, S. C. 1996. A Partial Instructional Module on Global and Regional Land Use/Cover Change: Assessing the Data and Searching for General Relationships. Geojournal, v. 39, n. 3, p. 241-283.

NASA; EOSDIS Land Processes DAAC; USGS Earth Resources Observation and Science (EROS) Center. 2015, Sioux Falls, South Dakota <https://lpdaac.usgs.gov>. MODIS Products (MOD13Q), 2010, access in 09/08/2016, at <https://e4ft|01.cr.usgs.gov/MOTA/MCD12C1.051/2002.01.01/>

Noma, A.; Korting, T. S.; Fonseca, L. M. G. Uma comparação entre classificadores usando regiões e perfis EVI para agricultura. In: Annals... XVI Simpósio Brasileiro de Sensoriamento Remoto. São José dos Campos: Instituto Nacional de Pesquisas Espaciais, 2013. p. 2250-2257. 
Pontius, R. G.; Li, X. Land transition estimates from erroneous maps. Journal of Land Use Science, v. 5, pp. 31-44. 2010.

Ruy, R. S.; Tommaselli, A. M. G.; Galo, M.; Hasegawa, J. K.; Reis, T. T. 2012. Accuracy Analysis Of Modular Aerial Digital System SAAPI In Projects Of Large Areas. EuroCOW, Commissions I and III, WG $I / 3,1 / 5,111 / 1,111 / 5$.

Sano, E. E.; Rosa, R.; Brito, J. L. S.; Ferreira, L. G. 2008. Mapeamento semidetalhado do uso da terra do Bioma Cerrado. Notas Científicas. Pesq. agropec. bras., v. 43, n. 1, p. 153-156, Brasília.

Sato, F. Y.; Souza, A. F.; Arai, E.; Adami, M.; Freitas, R. M.; Mello, M. P.; Rudorff, B. F. T.; Shimabukuro, Y. E. 2011. Distribuição de produtos Modis via interface web. In: Annals... XV Simpósio Brasileiro de Sensoriamento Remoto - SBSR, Curitiba, PR, Brazil, 2011, INPE p. 75027508.

Stehman, S. V. 2001. Statistical rigor and practical utility in thematic map accuracy assessment. Photogrammetric Engineering and Remote Sensing, v. 67, pp. 727-734.

Turner II, B. L.; Meyer, B. L. 1994. Global Land Use and Land Cover Change: An Overview. In: MEYER, W. B.; TURNER II, B. L. (eds). Changes in land use and land cover: a global perspective. Cambridge: Cambridge University Press, p. 3-10.

Turner II, B. L.; Skole, D. L.; Sanderson, S.; Fischer, G.; Fresco, L.; Leemans, R. 1995. Land-use and land-cover change: science/research plan. IGBP Report, n. 35, HDP Report, n. 7. IGBP and HDP, Estocolm and Genova.

Veldkamp, A.; Verburg, P. H.; Kok, K.; Koning, G. H. J.; Priess, J. ; Bergsma, A. R. 2001. The need for scale sensitive approaches in spatially explicit land use change modeling. Environmental Modeling and Assessment, v. 6, p. 111-121.

Wardlow, B. D.; Egbert, S. L.; Kastens, J. H. 2007.Analysis of time-series MODIS 250 m vegetation index data for crop classification in the U.S. Central Great Plains. Remote Sensing of Environment, v. 108, n. 3, p. 290-310.

Wright, J. 1982. Ground and air survey for field scientists. Oxford: Clarendom Press, 327p. 